\title{
Editorial
}

\section{Rbem: consolidação de um campo acadêmico e científico}

Lilian Koifman*

Este editorial registra um momento especial e delicado pelo qual a Revista e a publicação de revistas científicas vêm passando. A Revista Brasileira de Educação Médica, em especial, se despede da direção do professor Sergio Rego, incansável e de capacidade invejável na condução da Revista. Nos cerca de 25 anos (com uma interrupção) à frente da Revista, foi capaz de acompanhar as mudanças no campo editorial, especialmente no campo da saúde, com maestria. Contando com o apoio e incentivo das diversas Diretorias da Abem e com a qualidade dos pareceristas e da equipe técnica da Abem, elevou a Revista a um nível hoje consagrado.

Por tudo isso, em nome do campo da Saúde e da Educação Médica, agradeço a dedicação e o apoio tão importantes para que agora possamos dar continuidade ao trabalho.

Começamos a ampliar e a renovar o corpo de revisores científicos da Revista e esperamos em breve reabrir o recebimento de novos artigos e diminuir o prazo entre a submissão e o primeiro parecer disponível para os autores. Aproveitamos para nos desculpar pela suspensão temporária do recebimento de novos artigos. Pretendemos regularizar a situação nos próximos meses e contamos com a compreensão de todos. Da mesma forma, nos empenharemos em dar continuidade à evolução da Revista, para aumentar seu prestígio e internacionalização.

Não poderemos desprezar os desafios que se apresentam à Rbem. As restrições financeiras para a publicação dificultam que seja oferecido acesso à Revista em língua inglesa, e estamos conscientes de que esse ainda será um grande desafio a enfrentar.

Já começamos a modernizar o sistema de submissão e estamos em processo de migração para o sistema Scholar One, pela SciELO. Em breve, começaremos a disponibilizar os artigos na forma ahead of print. Enfim, trata-se de desafios inerentes ao trabalho de uma revista científica que, felizmente, podemos dizer que somos.

Ademais, vamos em frente com nossa produção, aproveitando temas tão importantes que vêm ocorrendo no campo, como a elaboração das Novas Diretrizes Curriculares, com pontos polêmicos e nova etapa em que as escolas médicas terão que adaptar seus currículos e realizar processos de ajuste e reformulação. Esse tema, bem como as avaliações do MEC e avaliações propostas por outras instituições como a Abem certamente também serão fontes inspiradoras de novos artigos que receberemos em breve!

Obrigada, Sergio, por me confiar "a criança"! Certamente, continuarei contando com sua ajuda, apoio e experiência. Agradeço também o apoio incansável da Rozane Landskron e a atuação da bibliotecária Danielle Torres, que tem sido estratégica para a estruturação e editoração da Revista. E a Helena Garbin, que assessora a editoração da Rbem em todas as etapas. 